\title{
A TANULÓK ÉNEKLÉSI ATTITÜDJÉRE HATÓ TÉNYEZŐK VIZSGÁLATA
}

\author{
VÁRADI JUDIT* - ÓVÁRY ZOLTÁN \\ Debreceni Egyetem Zenemüvészeti Kar
}

Beérkezett: 2020. november 12., elfogadva: 2021. május 20.

\begin{abstract}
A tanulmány egy empirikus kutatás eredményét mutatja be, melynek célja négy közép-európai ország 19 iskolájában folyó zenei nevelési gyakorlat elemzése és a tanulók $(N=805)$ zenei kultúrájának kialakulására ható tényezők vizsgálata. A szakirodalmi előzmények ismeretében a felmérés feltérképezi az egyes országok oktatási sajátosságai közötti hasonlóságot és különbséget. Kiemelten vizsgálja a 8-15 éves tanulók énekléshez füződő attitűdjét és az azt befolyásoló tényezőket, rávilágít a szülők kulturális tőkéjének hatására. Eredményeink szerint a különböző országok eltérő tananyaga és módszertani útmutatója ellenére a tevékenységközpontú, élményalapú oktatás iránymutató pedagógiai módszer a művészeti nevelés területén.
\end{abstract}

Kulcsszavak: zenei nevelés, éneklési attitűd, zenei aktivitás

The study presents the results of an empirical research, the aim is analysing the music education in 19 schools of four Central European countries and examining the factors influencing the development of students' musical culture $(N=805)$. Based on the background of the literature, the survey maps the similarities and differences between the educational peculiarities of each country. It examines the 8-15 years old pupils' attitudes towards singing and the underlying factors, as well as the impact of parents' cultural capital. According to our results, despite the different curricula and methodological guidelines of different countries, activity-based, experience-based education is a guiding pedagogical method in the field of arts education.

Keywords¥ music education, singing attitudes, music activity

\footnotetext{
* Levelező szerző: Váradi Judit, Debreceni Egyetem Zeneművészeti Kar, 4032 Debrecen, Nagyerdei körút 82. E-mail: judit.varadi.06@gmail.com
} 


\section{Elméleti háttér}

A tantárgyakkal kapcsolatos pedagógiai kutatások gyakran csak az „akadémikus” tárgyakra fókuszálnak, a készségtantárgyak, a Kontra Györgytől származó meghatározás szerint az „örömtantárgyak” (mint például az ének-zene, rajz) (Báthory 1997) gyakran kimaradnak. továbbá az eredményeket jelentősen befolyásolják a tantárgyakkal kapcsolatos attitüdök affektív (érzelmi-akarati) tényezői.

A tanulók szempontjából a tananyag három dimenzióban értelmezhető: érdekesunalmas, szükséges-szükségtelen, könnyü-nehéz (Takács 2001). Jellegzetesen könynyűnek és érdekesnek tartott tantárgyak a rajz, testnevelés és az ének. Báthory (1997) felmérésének eredményei alapján a 4. és 8. osztályosok körében a legkedveltebb tantárgy egyaránt a testnevelés, amelyet a rajz, technika és negyedik helyen az ének-zene követett. McPherson és O’Neill (2010) kilenc-huszonegy éves gyermekek és fiatalok körében vizsgálta meg a zene és öt másik tantárgy preferenciáját. Az eredmények azt mutatták, hogy iskolai tantárgyként a zenét kevésbé értékelték és alacsonyabb feladat-nehézségi besorolást kapott, mint a matematika és a művészetek, de magasabbra értékelték, mint a fizika és az anyanyelvi tantárgyat.

Hazai és nemzetközi kutatások az ének-zene tanításának általános fejlesztő hatásával is foglalkoztak, melyek a zeneoktatás tanulmányi eredményességre gyakorolt hatásai mellett vizsgálták a szocioemocionális képességek fejlődésére gyakorolt hatásokat is (Knappek 2002, Janurik 2008). Ezen felül vannak kutatások, amelyek az általános iskolai tanulók klasszikus zenéhez füződő attitűdjét veszik górcső alá (Roulston 2006, Guth 2006, Schmidt 2012). Brand (1986) kutatásában kimutatta, hogy az iskolai énekzene órákhoz füződő attitűdöt befolyásolják az iskolán kívüli zenei élmények, a szülők hozzáállása, valamint a szülők és gyermekek közös zenélése, együtt éneklése.

A zenei tevékenységek preferálására a nemek közötti különbség is kihathat (Lucas 2011). A tantárgyi kötődések terén Báthory (1989) vizsgálatai alapján a lányok a teljes vizsgált populációban statisztikailag szignifikáns módon jobban kedvelik a magyar nyelvet és irodalmat, valamint az ének-zenét. Kutatási eredmények arra is rámutatnak, hogy a lányok magasabb kompetenciát mutattak a zenei tantárgyból, mint a fiúk (McPhersonO’Neill 2010). Mizener (1993) eredményei szerint a lányok 87\%-a szeret énekelni, míg a fiúk 64\%-a kedveli ezt a zenei tevékenységet, a legtöbb diák a körülményektől függetlenül szívesen énekel. Erre alapozva feltételezik, hogy a jó éneklési készségek, a zenében elért sikerélmények magabiztosabbá teszik a gyermekeket, pozitívabb hozzáállást eredményeznek a zenéhez és az énekhez, mint tantárgyhoz, így a tanároknak ezt a pozitív hozzáállást kellene erősítenie (Siebenaler 2006).

Vizsgálatunk alapvető célja annak feltérképezése, hogy az éneklés által a zenei élmény megjelenik-e a tanórán, továbbá, hogy szeretnek-e a gyermekek énekelni és mi befolyásolja éneklési attitűdjüket. Ennek érdekében vizsgáltuk azokat a gyakorlati jellegű tanórai tevékenységeket - mint például az éneklés, ritmushangszerek használata, kóruséneklés -, amelyek valódi individuális, vagy közösségi élményt jelentenek a tanulóknak és közelebb hozza számukra a zenét. Kutatási kérdésként azt fogalmaztuk meg, hogy ezek a pedagógiai szegmensek jelen vannak-e az ének-zene órákon és hogy nemek szerint, illetve magyar, román, szerb és szlovák iskolák és tanulói adatai alapján nemzetközi összehasonlításban milyen különbségeket találunk a mindennapi gyakorlatban. 


\section{A vizsgált országok zenepedagógia történetének áttekintése}

Magyarországon az intézményesített zeneoktatás immár másfél évszázados múltra tekint vissza. Mind a szakmai, mind a döntéshozói oldalról megfogalmazódott az igény arra, hogy nem csak a tehetségek nevelésére van szükség, hanem a szerényebb képességü tanulóknak is lehetőséget kell biztosítani. A huszadik század második felének zenepedagógiai irányelveit egyértelműen Kodály (és követői) határozták meg Magyarországon. Maga a Kodály-koncepció nem ennek a korszaknak a termése, azonban a megfelelő támogatást ezen időszakban élvezhette leginkább. A kodályi nevelési elvek rövid összefoglalása szinte lehetetlen. A sokszor helytelenül Kodály-módszernek titulált oktatás és zeneoktatás filozófia nem egy kidolgozott módszertan vagy tanterv volt, hanem olyan Kodálytól származó „bölcsességek” és iránymutatások összessége, melyek beszédekből, írásokból, idézetekből, vagy kéziratokból maradtak ránk. A kodályi pedagógia hívei ezeken keresztül szinte mozaik-szerűen rakták össze a zenetanítás koncepcióját (Kodály 1982).

Románia intézményesített zenepedagógiája az ezernyolcszázas évek közepére nyúlik vissza. A leginkább francia mintákat követő oktatás a templomi szolgálatra való felkészítést, ezáltal az éneklést, a hangképzést és a kottaolvasást tüzte ki céljául. Ahogyan azt Lakatos (1938) könyvében megfogalmazta: „A románság nemzeti élete fiatal, így müzenéje sem tarthatott lépést a nyugat-európai muzsika fejlödésével." (Lakatos 1938: 3) Az 1950-es években a szovjet mintára alapozott közoktatás meglehetősen háttérbe szorította az általános iskolai énekórákat, a zenei nevelés leginkább a közoktatástól független zeneiskolák feladata lett. A klasszikus zene tanulásának lehetőségén túl a diákok választhatták az úgynevezett „népi müvészeti iskolákat” is. Romániában feltehetőleg a komolyzene oktatása nagy hangsúlyt kaphatott, mivel a Ceauşescu diktatúrában, a politikai elnyomás miatt a nyugati beatkultúra nem éreztethette olyan szinten a hatását, mint például a kádári Magyarország 1956 utáni puhább, engedékenyebb érájában (Szentkirályi 2015).

Szerbia már az ezerhétszázas évek vége óta rendelkezett zeneiskolákkal, de a zenetanítás színhelyei inkább a kolostorok és az egyházi iskolák voltak. A szerb területeken a török uralom az iskolarendszer elmaradottságát eredményezte. Sokáig csak hat osztályos elemi iskolák működtek, ahol a zene csak minimális szerepet kapott. A tizenkilencedik században már kifejezetten a bécsi és grazi mintákat követve hoztak létre zeneiskolákat. 1950-ben kezdődött az az iskolareform, melynek köszönhetően a nyolc osztályt és az énekoktatást minden évfolyamon bevezették. Jugoszláviában az általános iskolai énekoktatásban az Orff módszer dominált, azonban számos szerb kezdeményezés is született a zeneoktatási metódusok megreformálására. Volt olyan ötlet, hogy az osztályteremben legyen ugyan hangszer, de az ne zongora, hegedű vagy ütő, hanem gitár legyen, elsősorban az olcsósága miatt. Joža Požgaj a zeneoktatás módszertanának megalkotója a kottaolvasás mellőzését szorgalmazta. Olyan módszeren dolgozott, amely Kodályéhoz hasonló kézjelekkel, szótagokkal, ismert melódiák szolmizálásával foglalkozott. Elterjedt volt még a Jaques-Dalcroz módszer is, olyannyira, hogy Zágrábban még külön ritmika-iskola is müködött (Hegyi 1996).

Szlovákiában a zenei oktatás jelentős változásokon ment át a 20-dik században. A két világháború között a tanítás színvonala emelkedett, amely magával vonzotta a zenei oktatást is. A '60-as évek megtorpanása után a '70-es évektől a zenei nevelés progresszív 
irányával a modernizációs törekvések hatására 1976-ban bevezették az „Ujj koncepció"-t. 1994-ben vezették be a Nemzeti Oktatási Programot, a Constantine-t, amely szerint a zenei nevelés célja az éneklés mellett legalább egy hangszer alapfokú játékának ismerete. A Constantine projekt törekvései azonban a gyakorlatban nem érvényesültek. A 2008-as Oktatási törvény regresszív interferenciát hozott a zeneoktatásba. Az alapfokú oktatásban a zenei nevelés a Müvészet és Kultúra oktatási terület része, az egész oktatási folyamat a zenéből indul ki és a zenéhez tér vissza (Váradi-Strenacikova 2017).

\section{Minta és módszerek}

Kutatásunk fókuszában egy összehasonlító vizsgálat állt, melyben négy ország hét városa és annak tizenkilenc általános iskolája szerepelt. Magyarországot Debrecen képviseli, Romániából Oradea (Nagyvárad), Satu Mare (Szatmárnémeti), Târgu Mureș (Marosvásárhely), Szerbiából Subotica (Szabadka), Szlovákiából pedig Komárno (Komárom) és Banska Bystrica (Besztercebánya) vett részt a kutatásban. Azért esett a választás ezekre a városokra, mert regionális jelentőségük hasonló, így nagyobb valószínűséggel zárhattuk ki a településtípusból adódó különbségeket. A minta $(N=805)$ megoszlása szerint Szerbiát 164, Magyarországot 268, Szlovákiát 102, Romániát 270 tanuló képviselte.

A nemek aránya az érdemben válaszoló tanulók körében $(N=750)$ közel egyenlö: 48,6\% fiú, 51,4\% lány. Hozzátéve, hogy a szigorú adatvédelmi szempontokat alkalmazva Szlovákiában az egyik iskolában ezt a kérdést nem engedték kitölteni, így 55 fö, azaz a teljes minta 6,8\%-a nem adta meg, hogy melyik nemhez tartozik. Az eredeti tervek szerint a vizsgált populáció célcsoportját a 8-13 éves diákok alkották, mivel azonban teljes osztályok töltötték ki a kérdőívet, így a mintába kerültek 13 évesnél idősebb diákok is (2,8\%), továbbá az előbb ismertetett okok miatt a tanulók 6,5\%-a nem adta meg életkorát. A minta tehát nem reprezentatív, így az eredmények nem jellemeznek egy országot, ugyanakkor az eredmények feltáró jelleggel bepillantást adhatnak egy-egy ország adott településén folyó zenei oktatási gyakorlatába.

Kutatásunk során kérdőíves felmérést alkalmaztunk. A téma jellegéből adódóan nem használhattunk standardizált formát, ezért saját mérőeszközt alkottunk. A papíralapú kérdőívet a gyermekek iskolai tanóra keretei között töltötték ki, a válaszadás anonim és önkéntes volt. A 46 kérdésből 41 kérdés feleletválasztós volt, ahol a válaszokat karikázással, illetve aláhúzással lehetett megadni, a nyílt kérdésekre pedig szöveges válasz beírásával válaszolhattak a tanulók. Az adatok feldolgozása során SPSS 22-es programot használtunk, a kiértékelést kétdimenziós kereszttábla és $\chi^{2}$-próbával, valamint logisztikus regresszió segítségével végeztük. A táblázatokban csak szignifikáns eredményeket tüntettük fel.

\section{Értékelés, eredmények}

Elsőként az ének-zene órához füződő attitűdöt mértük fel. Az összes tanuló közül 777 érvényes választ kaptunk arra a kérdésre, hogy szereti-e az énekórát, csaknem nyolctizedük (79,3\%) pozitív, több mint ötödük $(20,7 \%)$ negatív érzelmet társított hozzá. 
Az előzetesen feltárt szakirodalmi kutatásokkal összhangban (Lucas 2011) megjelenik a nemek közötti eltérés. A lányok között szignifikánsan többen preferálják ezt a tantárgyat, mint a fiúk között (1. táblázat).

1. táblázat: Az ének-zene tantárgyhoz füződő attitűd nemek szerinti megoszlásban (\%)

\begin{tabular}{lcccc}
\hline \multirow{2}{*}{ Feltett kérdés } & & \multicolumn{2}{c}{ Nem } & Összesen \\
\cline { 3 - 4 } & & Fiú $(N=348)$ & Lány $(N=376)$ & $(N=724)$ \\
\hline Szereted-e az & igen & 69,7 & 89,4 & 79,9 \\
énekórát? & nem & 30,3 & 10,6 & 20,1 \\
\hline Összesen & & 100,0 & 100,0 & 100,0 \\
\hline
\end{tabular}

Megjegyzés: $\chi^{2}$-próba, $p<0,001$.

Forrás: Saját adatbázis

Országonkénti megoszlásban a szerb tanulók szeretik a legjobban az ének-zene órákat, a magyar és román tanulók után a szlovák tanulók közel 20\%-ponttal kevesebben preferálják a tantárgyat (2. táblázat).

2. táblázat: Az ének-zene tantárgyhoz füződő attitüd országok szerinti megoszlásban (\%)

\begin{tabular}{lcccccc}
\hline Feltett kérdés & \multicolumn{4}{c}{ Ország } & Összesen \\
\cline { 2 - 5 } & & $\begin{array}{c}\text { Magyarország } \\
(N=259)\end{array}$ & $\begin{array}{c}\text { Románia } \\
(N=267)\end{array}$ & $\begin{array}{c}\text { Szerbia } \\
(N=152)\end{array}$ & $\begin{array}{c}\text { Szlovákia } \\
(N=99)\end{array}$ & $(N=777)$ \\
\hline Szereted-e az & igen & 82,2 & 79,4 & 83,6 & 64,6 & 79,3 \\
énekórát? & nem & 17,8 & 20,6 & 16,4 & 35,4 & 20,7 \\
\hline Összesen & & 100,0 & 100,0 & 100,0 & 100,0 & 100,0 \\
\hline
\end{tabular}

Megjegyzés: $\chi^{2}$-próba, $p<0,001$.

Forrás: Saját adatbázis

A zenetanulás gyakorlata és ezáltal annak élményszerűvé tétele véleményünk szerint a zenélés legalapvetőbb formájával, az énekléssel kezdődik. A szakirodalomból ismert kutatásokat (Mizener 1993) megerősítve azt találtuk, hogy a lányok szignifikánsan szívesebben énekelnek, mint a fiúk (3. táblázat).

3. táblázat: Az énekléshez füződő attitűd nemek szerinti megoszlásban (\%)

\begin{tabular}{lcccc}
\hline Feltett kérdés & & \multicolumn{2}{c}{ Nem } & Összesen \\
\cline { 3 - 4 } & & Fiú $(N=363)$ & Lány $(N=379)$ & $(N=742)$ \\
\hline Szeretsz-e & igen & 68,0 & 90,0 & 79,2 \\
énekelni? & nem & 32,0 & 10,0 & 20,8 \\
\hline Összesen & & 100,0 & 100,0 & 100,0 \\
\hline
\end{tabular}

Megjegyzés: $\chi^{2}$-próba, $p<0,001$.

Forrás: Saját adatbázis 
A diákokat a felmérés során megkérdeztük arról, hogy énekelnek-e az órán, és ha igen, akkor megítélésük szerint milyen gyakran (válaszlehetőségek: soha, ritkán, gyakran). Kíváncsiak voltunk továbbá arra is, hogy a tanár énekel-e az órán, mivel élmény szempontjából az élőzenei előadás hatása ebben az esetben jobban érvényesül, a gyermekek látják, hogyan születik a hang, hogyan kell hangot képezni, levegőt venni, az előadónak milyen gesztusai vannak (Váradi 2010). A 4. táblázatban az igen válaszokat és azokon belül a szubjektív gyakoriságukat tüntettük fel. Ezekben az esetekben inkább az éneklés gyakoriságában láthatók különbségek. Nagyon érdekes, hogy Magyarország, Szerbia és Szlovákia esetében közel azonos eredményt kaptunk a tanár és a tanulók éneklési gyakoriságánál, Romániában azonban a tanulók véleménye szerint a tanár sokkal többet énekel, mint ők. A kedvtelésből való éneklés szerepeltetése a táblázatban azért releváns, mert megtudjuk belőle, hogy az éneklés élményt jelent-e egyáltalán a tanulóknak. A saját szórakozásból történő éneklés Magyarországon, Szerbiában és Szlovákiában kicsit kevesebb, mint az iskolai énekórán való éneklés, ugyanakkor Romániában énekelnek a legtöbbet a gyermekek saját elhatározásukból (4. táblázat).

4. táblázat: Az énekléshez füződő attitűd országonkénti megoszlása (igen válaszok megoszlása, \%)*

\begin{tabular}{|c|c|c|c|c|}
\hline Kérdés/Ország & Magyarország & Románia & Szerbia & Szlovákia \\
\hline $\begin{array}{l}\text { Énekel-e órán } \\
\text { a tanár? }\end{array}$ & $\begin{array}{c}98,9 \\
\text { (ritkán 10,1 } \\
\text { gyakran: 88,8) }\end{array}$ & $\begin{array}{c}97,8 \\
\text { (ritkán: } 19,8 \\
\text { gyakran: } 78,0 \text { ) }\end{array}$ & $\begin{array}{c}98,8 \\
\text { (ritkán: } 28,4 \\
\text { gyakran: } 70,4 \text { ) }\end{array}$ & $\begin{array}{c}98,0 \\
\text { (ritkán: } 12,0 \\
\text { gyakran: } 86,0 \text { ) }\end{array}$ \\
\hline $\begin{array}{l}\text { Énekelnek-e } \\
\text { a diákok órán? }\end{array}$ & $\begin{array}{c}98,1 \\
\text { (ritkán: } 10,5 \\
\text { gyakran: } 87,6 \text { ) }\end{array}$ & $\begin{array}{c}66,0 \\
\text { (ritkán: } 31,6 \\
\text { gyakran: } 36,4 \text { ) }\end{array}$ & $\begin{array}{c}96,3 \\
\text { (ritkán: } 25,9 \\
\text { gyakran: } 70,4 \text { ) }\end{array}$ & $\begin{array}{c}97,0 \\
\text { (ritkán: 9,9 } \\
\text { gyakran: } 87,1 \text { ) }\end{array}$ \\
\hline $\begin{array}{l}\text { Szoktál-e } \\
\text { saját kedvedre } \\
\text { énekelni? }\end{array}$ & $\begin{array}{c}93,5 \\
\text { (ritkán: } 35,5 \\
\text { gyakran: } 58,0 \text { ) }\end{array}$ & $\begin{array}{c}95,9 \\
\text { (ritkán: } 34,9 \\
\text { gyakran: 61,0) }\end{array}$ & $\begin{array}{c}90,3 \\
\text { (ritkán: } 29,7 \\
\text { gyakran: } 60,6 \text { ) }\end{array}$ & $\begin{array}{c}82,2 \\
\text { (ritkán: 44,6 } \\
\text { gyakran: } 37,6 \text { ) }\end{array}$ \\
\hline
\end{tabular}

Megjegyzés: *Mindhárom kérdésnél a három válaszkategória alapján számolt $\chi^{2}$-próba, $p<0,001$. Forrás: Saját adatbázis

$\mathrm{A} z$ ének-zene óra élményszerüségét erősíti, ha a gyermekeknek alkalmuk van hangszeren játszani. Kíváncsiak voltunk arra, hogy a tanulók szoktak-e - van-e lehetőségük ritmushangszereket használni. Az eredmények alapján a Szlovákiában tanulók kimagas-

5. táblázat: A ritmushangszerek használatának országonkénti megoszlása (\%)

\begin{tabular}{lcccccc}
\hline Feltett kérdés & \multicolumn{4}{c}{ Ország } & Összesen \\
\cline { 3 - 6 } & & $\begin{array}{c}\text { Magyarország } \\
(N=266)\end{array}$ & $\begin{array}{c}\text { Szerbia } \\
(N=162)\end{array}$ & $\begin{array}{c}\text { Románia } \\
(N=270)\end{array}$ & $\begin{array}{c}\text { Szlovákia } \\
(N=101)\end{array}$ & $(N=799)$ \\
\hline Énekórán & sokszor & 4,5 & 5,8 & 5,2 & 29,7 & 8,2 \\
$\begin{array}{l}\text { szoktatok-e } \\
\text { ritmushangszert }\end{array}$ & néha & 66,2 & 57,6 & 40,0 & 45,5 & 53,0 \\
használni? & soha & 29,3 & 36,6 & 54,8 & 24,8 & 38,8 \\
\hline Összesen & 100,0 & 100,0 & 100,0 & 100,0 & 100,0 \\
\hline
\end{tabular}

Megjegyzés: $\chi^{2}$-próba, $p<0,001$.

Forrás: Saját adatbázis 
lóan többször színesítik az énekórát ritmushangszerekkel, ami várható eredmény annak tudatában, hogy az Orff-módszer a nemzeti alaptantervük része (5. táblázat).

Az ének-zene órák közösségépítő tevékenysége, együttmuzsikálási alkalma a többszólamú éneklés, amelynek egyszerü formája a kánon éneklése. Az országonkénti megoszlás szerint a szerb tanulók több mint egynegyede, a szlovák tanulók több mint egyötöde nem szokott kánont énekelni az órán. Összességében a gyakoriságeltérés ellenére a gyermekek nagy része minden országban találkozik a többszólamú éneklés élményével, a pedagógusok nagy arányban alkalmazzák - még ha eltérő rendszerességgel is - az énekóráikon a közös éneklést mint a zenei nevelés egyik alaptevékenységét (6. táblázat).

6. táblázat: A kánonéneklés országonkénti megoszlása (\%)

\begin{tabular}{|c|c|c|c|c|c|c|}
\hline \multirow[t]{2}{*}{ Feltett kérdés } & & \multicolumn{4}{|c|}{ Ország } & \multirow{2}{*}{$\begin{array}{l}\text { Összesen } \\
(N=799)\end{array}$} \\
\hline & & $\begin{array}{l}\text { Magyarország } \\
(N=266)\end{array}$ & $\begin{array}{c}\text { Szerbia } \\
(N=161)\end{array}$ & $\begin{array}{l}\text { Románia } \\
(N=271)\end{array}$ & $\begin{array}{l}\text { Szlovákia } \\
(N=101)\end{array}$ & \\
\hline \multirow{3}{*}{$\begin{array}{l}\text { Énekórán } \\
\text { szoktatok-e } \\
\text { kánont énekelni }\end{array}$} & sokszor & 27,1 & 7,5 & 21,8 & 32,7 & 22,0 \\
\hline & néha & 65,4 & 65,2 & 64,2 & 45,5 & 62,5 \\
\hline & soha & 7,5 & 27,3 & 14,0 & 21.8 & 15,5 \\
\hline Összesen & & 100,0 & 100,0 & 100,0 & 100,0 & 100,0 \\
\hline
\end{tabular}

Megjegyzés: $\chi^{2}$-próba, $p<0,001$.

Forrás: Saját adatbázis

Az általános iskolai évek alatt a gyermekek zenei oktatásában az éneklés az elsődleges aktív tevékenység. Kutatások központi témája, hogy ennek ellenére a kórusokon való részvétel gyakorisága viszonylag kicsi és az általános iskolához képest a későbbiek során egyre csökken (Mizener 1993) annak ellenére, hogy a kóruséneklés mint közösségi tevékenység segíti a szocializációs folyamatot (Siebenaler 2006). Ezért felmérésünk során arra is kíváncsiak voltunk, hogy az általunk vizsgált gyermekek részt vesznek-e kórusfoglalkozásokon. Kutatásunk során a nemek közötti eltérés már az éneklési attitüdben és az énekóra preferálásában is megmutatkozott alátámasztva az eddigi kutatásokat (Mizener 1993; Lucas 2011), így nem meglepő az az eredmény, miszerint a kóruséneklésben a lányok 35\%-a vesz részt, míg a fiúknak csupán 19,1\%-a (7. táblázat).

7. táblázat: Az énekkarban történő éneklés nemek szerinti megoszlása (\%)

\begin{tabular}{lcccc}
\hline Feltett kérdés & & \multicolumn{2}{c}{ Nem } & Összesen \\
\cline { 3 - 4 } & & Fiú $(N=363)$ & Lány $(N=385)$ & $(N=748)$ \\
\hline Énekelsz-e & igen & 19,1 & 35,0 & 27,2 \\
énekkarban? & nem & 80,9 & 65,0 & 72,8 \\
\hline Összesen & & 100,0 & 100,0 & 100,0 \\
\hline
\end{tabular}

Megjegyzés: $\chi^{2}$-próba, $p<0,001$.

Forrás: Saját adatbázis 
$\mathrm{A} z$ eredmények azt is mutatják, hogy Magyarországon és Szerbiában a tanulók több mint háromtizede énekel énekkarban, Romániában kevesebb mint egynegyedük, Szlovákiában pedig kevesebb mint egyhatoduk (8. táblázat).

8. táblázat: Az énekkarban történő éneklés országonkénti megoszlása (\%)

\begin{tabular}{|c|c|c|c|c|c|c|}
\hline \multirow[t]{2}{*}{ Feltett kérdés } & & \multicolumn{4}{|c|}{ Ország } & \multirow{2}{*}{$\begin{array}{l}\text { Összesen } \\
(N=802)\end{array}$} \\
\hline & & $\begin{array}{c}\text { Magyarország } \\
(N=268)\end{array}$ & $\begin{array}{c}\text { Szerbia } \\
(N=162)\end{array}$ & $\begin{array}{c}\text { Románia } \\
(N=271)\end{array}$ & $\begin{array}{l}\text { Szlovákia } \\
(N=101)\end{array}$ & \\
\hline \multirow{2}{*}{$\begin{array}{l}\text { Énekelsz-e } \\
\text { énekkarban? }\end{array}$} & igen & 31,3 & 30,9 & 22,6 & 16,2 & 26,4 \\
\hline & nem & 68,7 & 69,1 & 77,4 & 83,8 & 73,6 \\
\hline Összesen & & 100,0 & 100,0 & 100,0 & 100,0 & 100,0 \\
\hline
\end{tabular}

Megjegyzés: $\chi^{2}$-próba, $p<0,001$.

Forrás: Saját adatbázis

A családból hozott kulturális tőke komponenseiből Bourdieu (1979) tipizálása alapján $a z$ intézményesült kulturális tőke és a bensővé tett, azaz az inkorporált kulturális tőke hatását vizsgáltuk az éneklési attitűdre logisztikus regresszióval. Az iskolai végzettség a kulturális kompetencia bizonyítéka, az inkorporált kulturális tőke titulusok formájában történő objektiválása során jön létre az intézményesült kulturális tőke. Az inkorporált kulturális tőke nem örökölhető, csak ráfordított idővel, energiával szerezhető meg, felhalmozását elsajátítási folyamat előzi meg. A vizsgálat függő változóját az jelentette, hogy a gyermek szeret-e énekelni $(0=$ nem, 1 = igen), a magyarázó változókat pedig az intézményesült és az inkorporált kulturális tőke komponensei jelentették, az apa, anya végzettsége, énekelnek-e a szülök (nem/igen), játszanak-e otthon valamilyen hangszeren (nem/ igen), jártak-e zeneiskolába (nem/igen). Jelen vizsgálatunkban sem az apa, sem az anya végzettsége nem bír magyarázó erővel a gyermek éneklési kedvére. A szülők hangszeres játéka szintén nem befolyásolja a gyermek énekléshez füződő attitűdjét, ugyanakkor a szülő korábbi zenei tanulmányai és a szülő éneklése szignifikánsan befolyásolja az éneklés szeretetét. Ha a szülö énekel, akkor több mint kétszeresére, ha pedig zeneiskolába járt, akkor csaknem másfélszeresére nő annak az esélye, hogy a gyermek is megszereti az éneklést (9. táblázat).

9. táblázat: A gyermek éneklési kedvét befolyásoló tényezők a logisztikus regresszió alapján $(N=775)$

\begin{tabular}{lccccc}
\hline Magyarázó változók & $\begin{array}{c}\text { Együttható } \\
(B)\end{array}$ & $\begin{array}{c}\text { Standard } \\
\text { hiba (S.E.) }\end{array}$ & Wald & Sig. & Exp(B) \\
\hline $\begin{array}{l}\text { A szülők énekelnek-e } \\
(0=\text { nem, } 1=\text { igen })\end{array}$ & 0,782 & 0,150 & 27,102 & 0,000 & 2,187 \\
\hline $\begin{array}{l}\text { A szüleid jártak-e zeneiskolába } \\
(0=\text { nem, } 1=\text { igen })\end{array}$ & 0,351 & 0,137 & 6,552 & 0,010 & 1,421 \\
\hline
\end{tabular}

Megjegyzés: Függő változó: 0 = nem szeret énekelni, 1 = szeret énekelni (fizetett munka). A táblázatban csak azok a változók szerepelnek, amelyek $p<0,05$ szinten szignifikánsak. Nagelkerke-pszeudó $R^{2}=0,076$. Találati arány: 78,8\%, Hosmer- és Lemeshow-teszt értéke, szignifikanciaértéke: 14,107; $p<0,05$.

Forrás: Saját adatbázis 
A család mint elsődleges szocializációs színtér rendkívül fontos szerepet tölt be az értékközvetítésben, elsődlegesen meghatározza a kulturális tőke hátterét, amelynek különböző típusai bizonyos mértékben átválthatók iskolai sikerekre (Fényes-Pusztai 2004; McPherson 2009). A kulturális érzékenyítés folyamatában nagy szerepe van a család után az iskolának, amely továbbépíti vagy esetlegesen pótolja, korrigálja a hiányosságokat (Ferge 1999). Általánosságban elmondható, hogy az iskola szerepe mindegyik kutatási helyszínen erőteljesen meghatározó. A családban történő daltanulásnak is van azért jelentősége, ugyanis arról a korosztályról beszélünk, akiknél még elevenen élhetnek a szülőktől, nagyszülőktől tanult mondókák, gyermekdalok (Várad, 2010). Az otthoni daltanulás tekintetében nem tapasztaltunk különbséget a vizsgált országokban, ugyanakkor az iskola daltanulásban betöltött szerepe kapcsán Magyarországon látható a legnagyobb arány, Szlovákiában a legkisebb (10. táblázat).

10. táblázat: Az otthoni, illetve iskolai daltanulás országonkénti megoszlása (\%)

\begin{tabular}{|c|c|c|c|c|c|c|}
\hline \multirow[t]{2}{*}{ Feltett kérdés } & & \multicolumn{4}{|c|}{ Ország } & \multirow{2}{*}{$\begin{array}{l}\text { Összesen } \\
(N=804)\end{array}$} \\
\hline & & $\begin{array}{l}\text { Magyarország } \\
(N=268)\end{array}$ & $\begin{array}{c}\text { Szerbia } \\
(N=162)\end{array}$ & $\begin{array}{c}\text { Románia } \\
(N=272)\end{array}$ & $\begin{array}{l}\text { Szlovákia } \\
(N=102)\end{array}$ & \\
\hline \multirow{2}{*}{$\begin{array}{l}\text { Hol tanultad a } \\
\text { dalokat, ami- } \\
\text { ket énekelsz? }\end{array}$} & otthon & 35,1 & 25,9 & 30,9 & 21,6 & 29,9 \\
\hline & $\begin{array}{l}\text { iskolá- } \\
\text { ban* }\end{array}$ & 67,5 & 51,2 & 56,3 & 35,3 & 56,0 \\
\hline Összesen & & 100,0 & 100,0 & 100,0 & 100,0 & 100,0 \\
\hline
\end{tabular}

Megjegyzés: * $\chi^{2}$-próba, $p<0,001$.

Forrás: Saját adatbázis

\section{Összegzés és következtetések}

Kutatásunk során kérdőíves felmérést végeztünk Debrecen, Subotica (Szabadka), Oradea (Nagyvárad), Satu Mare (Szatmárnémeti), Târgu Mureș (Marosvásárhely), Komárno (Komárom) és Banska Bysrtica (Besztercebánya) általános iskoláiban. Arra voltunk kíváncsiak, hogy az ott zajló ének-zene órákhoz milyen attitüddel viszonyulnak a tanulók, mennyire gyakorlatias jellegü az oktatás, kellő hangsúlyt kap-e az éneklés mint aktív tevékenység.

A vizsgálatunkban részt vevő tanulók több mint háromnegyede pozitívan viszonyul az énekórához. Az elözetesen feltárt és a tanulmányban bemutatott szakirodalmi kutatásokkal összhangban a kiértékelés során eltérés mutatkozott a nemek között, a lányok többsége jobban preferálja ezt a tantárgyat és szívesebben énekel. Az ének-zene óra élményszerűségét erősíti, ha az éneklés mellett a gyermekeknek alkalmuk van ritmushangszereket használni. Az eredmények alapján megállapítottuk, hogy a kurrikulum módszertan alapján Szlovákiában sokkal többször színesítik az énekórát ritmushangszerekkel, mint a többi országban. Az általunk vizsgált gyermekek közül Magyarországon és Szerbiában a tanulók kevesebb mint egyharmada énekel énekkarban, Romániában viszont kevesebb mint egyegyedük, Szlovákiában pedig kevesebb mint egyhatoduk. Ez annak ismeretében alacsony érték, hogy a szakirodalmi kutatások azt prognosztizálják, 
hogy a kórusokban való részvétel gyakorisága az általános iskolához képest a későbbiek során egyre csökken (Mizener 1993).

A családnak rendkívül fontos szerepe van az értékközvetítésben, ugyanakkor ebben a korosztályban már az iskola szerepe is kimagasló, amely tovább építi a kulturális tőkét. Összefoglalóan megállapíthatjuk, hogy a különböző országok eltérő tananyaga és módszertani útmutatója ellenére a zenei nevelés aktív tevékenysége közül az éneklés és a ritmushangszerek használata mindenhol jelen van. A tanár maga is énekel, amely élőzenei bemutatóként a zenehallgatás legtermészetesebb formája, érzelmileg jobban megfogja a gyermeket (Váradi 2010). A müvészeti oktatás során a pedagógus feladata nem az ismeret átadása, hanem az alkotás, tapasztalás élményének megteremtése, az érzékenyítés. A tanulói és tanulási attitűdöt befolyásolja a szaktanár tudása, módszertani kultúrája, pedagógusi kreativitása. A tevékenységközpontú, élményalapú oktatás iránymutató pedagógiai módszer a művészeti nevelés területén, a színvonalas művészetoktatás a kor kihívásaihoz alkalmazkodva magasan képzett tanárokat feltételez.

\section{IRODALOM}

BÁthory Z. (1989) Tantárgyi kötődések vizsgálata négy tanulói korosztály körében. Monitor ,86. Pedagógiai Szemle,12.1162-1172.

Bát Hory Z. (1997) Tanulók, iskolák - különbségek. Egy differenciális tanitáselmélet vázlata. Budapest, Okker Kiadó.

Bourdieu, P. (1979) Distinction: A Social Critique of the Judgement of Taste. Massachusetts,Cambridge, Harvard University Press.

Brand, M. (1986) Relationship between Home Musical Environment and Selected Musical Attributes of Second-grade Children. Journal of Research in Music Education, Vol. 3. No. 4. pp. 111-120.

Fényes H. \& Pusztai G. (2004) A kulturális és a társadalmi tőke kontextuális hatásai az iskolában. Statisztikai Szemle, Vol. 82. Nos 6-7. pp. 567-582.

Ferge Zs. (1999) A társadalmi struktúra és az iskolarendszer közötti összefüggés. In: MELeg Cs. (ed.) Iskola és társadalom. Pécs, JPTE Tanárképző Intézet Pedagógia Tanszéke. pp. $10-30$.

Hegri I. (1996) Világunk zeneoktatási öröksége. Pécs, Janus Pannonius Tudományegyetem.

Gutн, P. (2006) The Importance of Music Education. http://education.more4kids.info/23/ the-importance-of-music-education/ [Letöltve: 2020. 04. 04.]

JANurik M. (2008) A zenei képességek szerepe az olvasás elsajátításában. Magyar Pedagógia. Vol. 108. No. 4. pp. 289-317.

KnappeK, R. (2002) The Effects of the Intensive Music Education for the General and Individual Development of Children. Survey in Berlin by Hans Günther Bastian about the Effects of the Extra Active Music-making. Hang és lélek. Új utak a zene és társadalom kapcsolatában. Zenei nevelési konferencia. Budapest, Magyar Zenei Tanács. pp. 95-108.

KodÁly Z. (1982) Visszatekintés. Összegyüjtött írások, beszédek, nyilatkozatok I. Budapest, Zeneműkiadó.

Lakatos I. (1938) A román zene fejlödéstörténete. Cluj, Minerva Irodalmi és Nyomdai Müintézet R.-T. 
Lucas, M. (2011) Adolescent Male Attitudes about Singing in Choir. National Association for Music Education, Vol. 30. No. 1. pp. 46-53.

McPherson, G. E. (2009) The Role of Parents in Children's Musical Development. Psychology of Music, Vol. 37. No. 1. pp. 91-110.

McPherson, G. E. \& O'Neill, S. A. (2010) Students' Motivation to Study Music as Compared to Other School Subjects: A Comparison of Eight Countries. Research Studies in Music Education, Vol. 32. No. 2. pp. 101-137.

Mizener, Ch. P. (1993) Attitudes of Children toward Singing and Choir Participation and Assessed Singing Skill. Journal of Research in Music Education, Vol. 41. No. 3. pp. 233245.

Roulston, K. (2006) Qualitative Investigation of Young Children's Music Preferences. International Journal of Education E the Arts, Vol. 7. No. 9. pp. 1-23.

Scrmidt, P. (2012) What We Hear Is Meaning Too: Deconstruction, Dialogue, and Music. Philosophy of Music Education Review, Vol. 20. No. 1. pp. 3-24.

Siebenaler, D. J. (2006) Factors that Predict Participation in Choral Music for HighSchool Students. Research and Issues in Music Education, Vol. 4. No. 1. pp. 1-8.

SzentKirályi A. M. (2015) Az izlandi, a romániai és a magyarországi zeneoktatás egyes elemeinek összehasonlító elemzése és ezek hatása a zenei kultúrára. Opus et Educatio, Vol. 2. No. 4. pp. 230-244.

TAkács V. (200I) Tantárgyi attitűdök struktúrája. Magyar Pedagógia, Vol. 101. No. 3. pp. 301-318.

Váradi, J. \& Strenacikova, M. (2017) The Perspectives of Music Education in Slovakia. Hungarian Educational Research Journal (HERJ), Vol. 7. No. 3. pp. 19-28.

VÁradi, J. (2010) How to Educate an Audience to Acquire a Taste for Classical Music. University of Jyväskylä. https://jyx.jyu.fi/bitstream/handle/123456789/24968/9789513938987. pdf?'sequence $=1$ [Letöltve: 2020. 03.22.]

A cikk a Creative Commons Attribution 4.0 International License (https://creativecommons.org/licenses/ by/4.0/) feltételei szerint publikált Open Access közlemény, melynek szellemében a cikk bármilyen médiumban szabadon felhasználható, megosztható és újraközölhető, feltéve, hogy az eredeti szerző és a közlés helye, illetve a CC License linkje és az esetlegesen végrehajtott módosítások feltüntetésre kerülnek. (SID_1) 